\title{
Quaternary faults of south-central Australia: palaeoseismicity, slip rates and origin
}

\author{
M. C. QUIGLEY*, M. L. CUPPER AND M. SANDIFORD
}

School of Earth Sciences, University of Melbourne, Vic. 3010, Australia.

\begin{abstract}
Faults bounding the Flinders Ranges of South Australia and the Barrier Ranges of New South Wales display clear evidence of significant Quaternary displacements. Kinematic analysis of the Wilkatana, Burra and Mundi Mundi Faults indicates that reverse-oblique fault slip occurred in response to eastwest compression, consistent with maximum compressive stress $\left(\mathrm{SH}_{\mathrm{Max}}\right.$ ) orientations derived from historical earthquake focal mechanisms. Surface-rupturing events resulted from a series of moment magnitude (M) $\geq 6.6$ palaeo-earthquakes over the past 100000 years. The timing of the most recent surface-rupturing events was determined on each fault from optically stimulated luminescence dating of faulted and post-faulting strata. The Wilkatana Fault has been the site of at least two major earthquakes since around $67 \mathrm{ka}$, making this one of the youngest prehistoric fault scarp exposures in Australia. Thickness estimates of faulted Pliocene and Quaternary footwall sediment imply minimum fault slip rates of $20-30 \mathrm{~m}$ per million years, while extrapolation of a domed planation envelope in the bedrock hangingwall to the fault plane yields fault slip rates of 36-51 m per million years. Movement at these rates over the Pliocene to Holocene interval accounts for a significant proportion of the contemporary relief in the Flinders Ranges. The relative intensity of neotectonic activity and historical seismicity in the Flinders Ranges reflects the role of structural and thermal heterogeneities in a regional stress field dominated by far-field plate-boundary forces.
\end{abstract}

KEY WORDS: earthquakes, faulting, intraplate, neotectonics, Quaternary faults, seismicity, southern Australia, stress.

\section{INTRODUCTION}

Large earthquakes occur intermittently in stable intraplate settings and may significantly impact developed and natural landscapes. The Australian continent experiences a magnitude $\geq 6.0$ earthquake about every five years, as indicated by the historical database (McCue 1990). While the historical record of these events provides an insight into the contemporary Australian intraplate stress field (Clark \& Leonard 2003), such datasets span relatively short time intervals $(<200 \mathrm{y})$ and are therefore unlikely to encompass an earthquake of maximum magnitude for most areas (Sandiford et al. 2004). Seismic-hazard assessments of intracontinental regions based on historical seismicity may thus underestimate seismic risk (Clark \& McCue 2003) and inadequately characterise long-term fault behaviour.

The neotectonic record of prehistoric faulting provides an important additional source of information on the long-term behaviour of intracontinental faults, especially where it can be linked to contemporary seismicity. The Australian continent has experienced at least five major surface-rupturing earthquakes since 1968 that have left a tectonic and geomorphic imprint (Crone et al. 1997), suggesting that similar prehistoric events may be preserved in the geological record. A recent emphasis has thus been to locate and study preserved fault scarps and fault-line escarpments in order to better understand the nature of intraplate seismicity (McCue 1990; Crone et al. 1997, 2003; Hill \& Kohn 1999; Clark et al. in press) and to evaluate the extent to which the historic record of seismicity is indicative of neotectonic activity at geological time-scales (Sandiford 2003).

Australia is generally considered a tectonically stable continental region (Johnston et al. 1994), where ancient land surfaces predominate (Twidale \& Bourne 1975; Ollier 1978; Twidale 1983). While this is manifestly true for much of the continent, in some areas the coincidence of enhanced contemporary seismicity and surprisingly youthful geomorphology imply an important role for neotectonic landsculpting. One such region is the Flinders Ranges of South Australia, one of the most seismically active and geomorphically rugged parts of the continent (Sprigg 1945; Sandiford 2003). A number of workers have described Quaternary thrusting along range-bounding faults (Williams 1973; Ollier 1978; Bourman \& Lindsay 1989, Célèrier et al. 2005), with fault slip rates in the range of $20-150 \mathrm{~m}$ per million years (Sandiford 2003). Sandiford (2003) traced this neotectonic regime back to at least $5 \mathrm{Ma}$ based on regional unconformities between Upper Miocene and Pliocene sequences, and suggested that as much as half of the present elevation of the Flinders-Mt Lofty Ranges may be attributed to the presently active regime.

*Corresponding author: m.quigley2@pgrad.unimelb.edu.au 
This study presents a new palaeoseismic analysis of the Late Quaternary tectonic activity associated with the Wilkatana and Burra Faults of the central Flinders Ranges and the Mundi Mundi Fault of the Barrier Ranges (Figure 1). Optically stimulated luminescence ages from fault-related sediments are used to generate quantitative palaeoseismic estimates. This allows better understanding of the long-term behaviour of intracontinental faults, including their temporal and spatial distribution and their potential for large-magnitude earthquake recurrence. The role and significance of active faulting in shaping the youthful topography and geomorphology of the Flinders Ranges are also considered. Specifically, the magnitude of vertical bedrock uplift resulting from movement along range-bounding faults was estimated in order to quantify the geomorphic signature associated with the active tectonic regime. Our results highlight the potential of intracontinental faults to impact the landscape, despite generally low slip rates and long recurrence intervals.

\section{IN SITU STRESS, SEISMICITY AND THE NEOTECTONIC RECORD IN SOUTH-CENTRAL AUSTRALIA}

The geodynamic framework for understanding the neotectonic evolution of south-central Australia is provided by the historical record of seismicity and the well-documented in situ stress field (Hillis \& Reynolds 2000; Clark \& Leonard 2003; Sandiford 2003). The Flinders Ranges form one of the most seismically active zones in the Australian continent (Figure 1), with hundreds of earthquakes annually and five magnitude $>5.0$ earthquakes in the past century (Greenhalgh et al. 1994).

The Flinders Ranges in situ stress field is primarily constrained by earthquake focal mechanisms. Greenhalgh et al. (1986, 1994) used mechanisms from seven Flinders Ranges earthquakes to calculate three dip-slip thrust and four strike-slip fault-plane solutions along north- to northeast-striking focal planes. A principle horizontal compressive stress orientation of $83 \pm 30^{\circ}$ was inferred (Greenhalgh et al. 1994; Hillis \& Reynolds 2000) (Figure 1b). Clark and Leonard (2003) documented a similar, incompatible combination of strike-slip and pure thrust mechanisms in the Flinders Ranges and derived a horizontal compressive stress azimuth of $82^{\circ}$ from the strike-slip set.

The Quaternary neotectonic record is dominated by north- to northeast-striking, range-bounding reverse faults recording approximately east-west shortening (Sandiford 2003). This consistency between inferred compressive stress orientations from historical and neotectonic datasets suggests that the active, roughly east-west compressional tectonic regime may
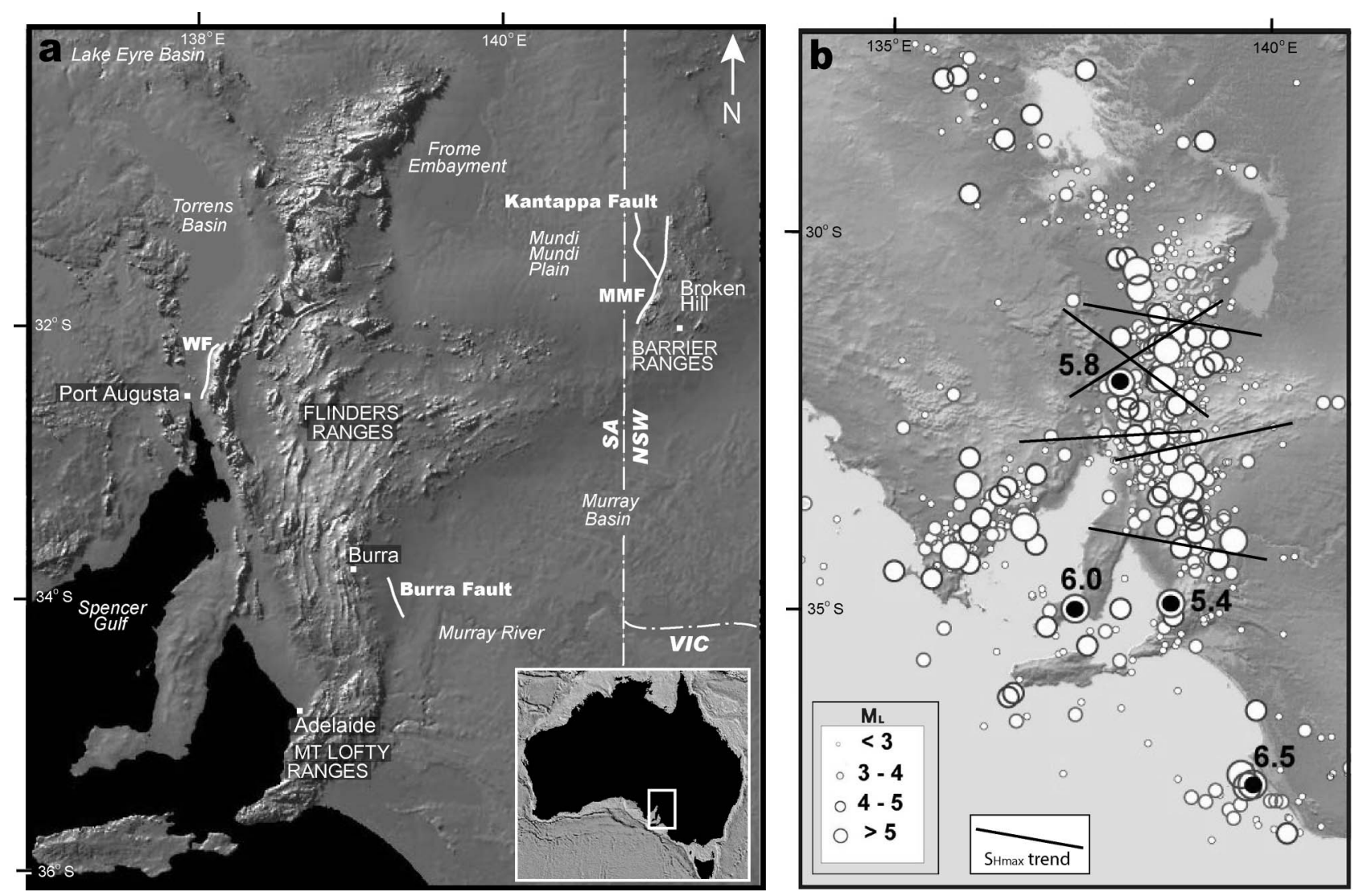

Figure 1 (a) Major physiographic features of south-central Australia [South Australia (SA), New South Wales (NSW) and Victoria (VIC)] in relation to the Wilkatana (WF), Burra, and Mundi Mundi Faults (MFS). (b) Distribution of south-central Australian historical seismicity, location of largest $\mathbf{M}$ earthquakes, and correlation with topography. Maximum horizontal principle compressive stress trends $\left(\mathrm{SH}_{\mathrm{Max}}\right)$ after Hillis and Reynolds (2000). 
be extrapolated over geological time-scales. Active strike-slip faults have not yet been recognised in the neotectonic record, quite possibly because they have not generated sufficient surface relief to be distinguished from older structures inherited from prior stages of tectonism. The apparent absence of young strike-slip faults in the neotectonic record presents a continuing challenge to this correlation.

The origin of the contemporary southeastern and south-central Australian in situ stress field has been attributed to interactions along the Pacific-Australian plate boundary associated with the generation of the Southern Alps of New Zealand at about 10-5 Ma (Coblentz et al. 1995, 1998; Sandiford 2003; Sandiford et al. 2004). We postulated that large earthquakes were likely to have occurred in south-central Australia subsequent to the $\geq 5 \mathrm{Ma}$ onset of the active tectonic regime.

\section{CENTRAL FLINDERS AND BARRIER RANGES}

The Flinders Ranges form part of an upland system extending some $600 \mathrm{~km}$ inland from the southern coast of South Australia in the vicinity of Adelaide to the Lake Eyre Basin (Figure 1). At about latitude $33^{\circ} \mathrm{S}$, the ranges bifurcate with an eastern branch of relatively subdued topography joining the Flinders Ranges sensu stricto with the Barrier Ranges in western New South Wales. The Wilkatana Fault is exposed along the western flank of the central Flinders Ranges (Figure 1). The adjacent catchments exceed $300 \mathrm{~m}$ in elevation, with peak elevations reaching $844 \mathrm{~m}$ at $\mathrm{Mt}$ Arden (Figure 2). This portion of the Flinders Ranges is particularly rugged, encompassing steep-sided rocky hillslopes with rock debris scars implying active landsliding.

The Burra Fault is located at Worlds End Creek on the eastern flank of the central Flinders Ranges (Figure 1). Local topography is subdued, with gently undulating hills rising $100-200 \mathrm{~m}$ above the piedmont surface.

The Mundi Mundi Fault defines the western flank of the Barrier Ranges and is cross-cut by the Kantappa Fault at $\sim 31^{\circ} 20^{\prime} S$ (Figure 1). The gently undulating topography of the interior ranges increases slightly at the range front, where maximum relief occurs over a distance of $<4 \mathrm{~km}$ from the peak elevations of Mt Robe (472 $\mathrm{m}$ ) to the adjacent Mundi Mundi Plain (250 m).

The bedrock geology of the Flinders and Barrier Ranges consists of a 5-12 km-thick package of Neoproterozoic to Cambrian rift sediments and minor volcanics of the Adelaide Geosyncline (Dalgarno et al. 1968) overlying Palaeoproterozoic metasedimentary and igneous rocks and Mesoproterozoic intrusives (Stevens \& Corbett 1993). Major faults such as the Mundi Mundi Fault may have originated during Neoproterozoic continental extension associated with the breakup of Rodinia (Stevens 1986; Gibson et al. 1997). Following rifting, the entire sequence was deformed during the contractional Late Cambrian-Early Ordovician ( $c a$ 500-490 Ma) Delamerian Orogeny, forming a distinctive oroclinal system now expressed in the strike-ridgedominated topography of the region. Reactivation

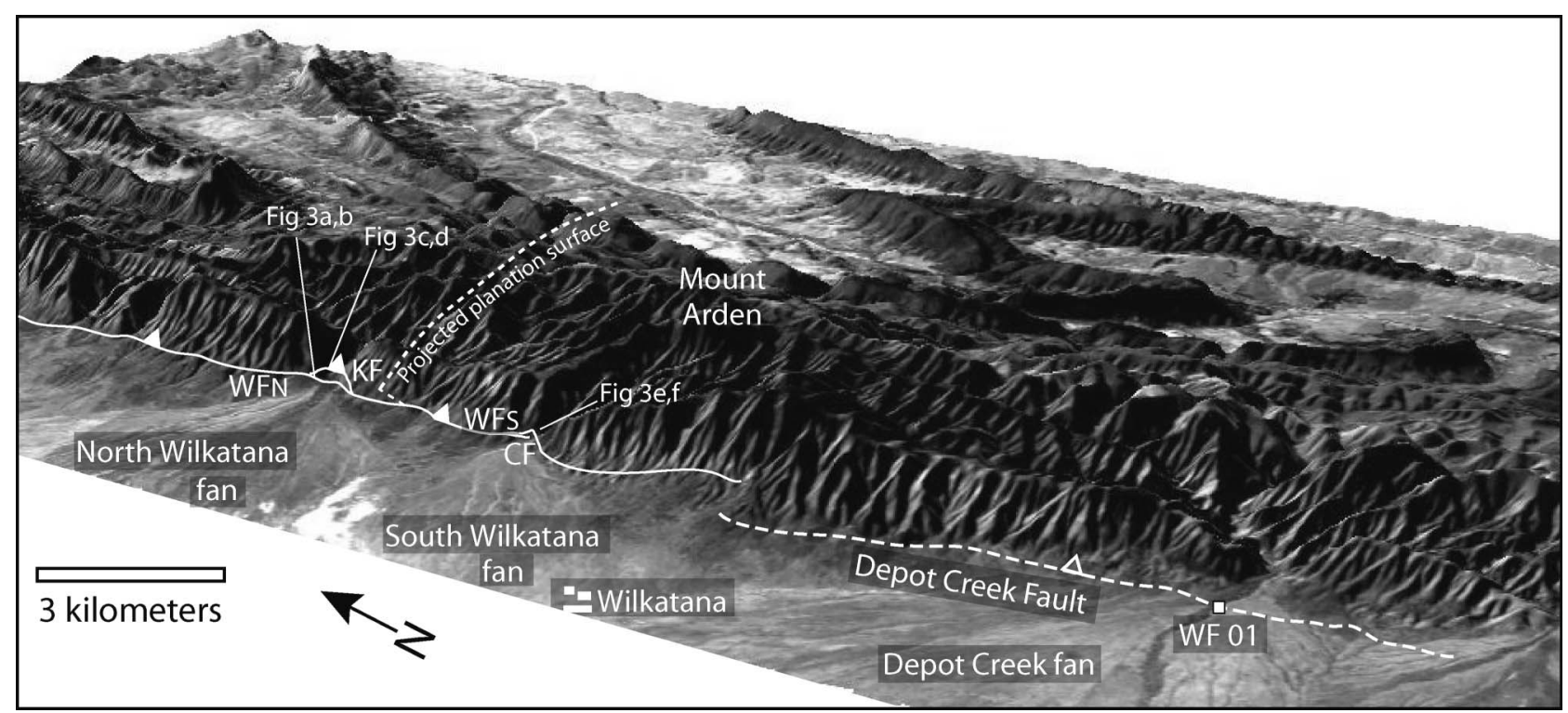

Figure 2 ASTER satellite image and underlying digital elevation map of the Wilkatana region, looking east-northeast. The Wilkatana Fault (solid line, teeth on hangingwall) was traced along a linear break-in-slope between the northern segment (WFN) and southern segment (WFS) exposures, and to the north and south of these exposures. We suggest that the Knickpoint (KF) and Cobble Faults (CF) may form strands of this master fault. We inferred the position of the Depot Creek Fault based on its subsurface location beneath the Depot Creek fan as indicated from drillhole and gravity data (Preiss \& Faulkner 1984), and inferred fault length from the length of the corresponding linear mountain front trace. The location of OSL sample WF 01 overlying the Depot Creek Fault is shown. We used an east-west trending, concave-down envelope intersecting the high peaks (projected planation surface) to determine the Pliocene to Holocene offset along the WF by intersecting this surface with the upward projection of the WF (right angle in dashed line). Geographical locations of subsequent figures shown. 
during the Devonian and Carboniferous Alice Springs events is indicated by low-temperature thermochronometers such as feldspar ${ }^{40} \mathrm{Ar} /{ }^{39} \mathrm{Ar}$ (McLaren et al. 2002) and apatite fission track (Hill \& Kohn 1999; Gibson \& Stüwe 2000).

The cratonic basement material is extraordinarily enriched in heat-producing elements, with many of these granitic gneisses having heat-production rates in excess of $10 \mu \mathrm{W} / \mathrm{m}^{3}$ (Neumann et al. 2000). Heat flows in the Flinders and Mt Lofty Ranges average $\sim 90 \mathrm{~mW} / \mathrm{m}^{2}$, with a high of $125 \mathrm{~mW} / \mathrm{m}^{2}$ in the northern Flinders Ranges. Neumann et al. (2000) suggested that the combination of high heat production and tectonic preconditioning has resulted in thermal weakening of the Flinders Ranges crust, thereby providing an additional explanation for the apparent proclivity of this region for accommodating tectonic activity (see also Célèrier et al. 2005).

\section{WILKATANA FAULT}

The Wilkatana Fault comprises a network of moderately to steeply east-dipping fault segments along the western range front $\sim 35 \mathrm{~km}$ north of Port Augusta. Fault segments are exposed along steeply incised river meanders at the mouth of the North and South Wilkatana catchments, where they cross-cut alluvial deposits. Visual analysis of ASTER satellite images indicate that a linear (low sinuosity), prominent break-in-slope is present along the range front between the northern and southern fault exposures (Figure 2). We thus infer that, although much of the Wilkatana Fault has been buried by hillslope alluvium along its strike length, the mapped fault segments form parts of a continuous fault of $\sim 13.8$ km length (Wilkatana Fault: Figure 2). The proximity of these fault exposures to the range front implies young activity on this portion of the Wilkatana Fault.

Drilling and geophysical investigations at the apex of the Depot Creek Fan (Preiss \& Faulkner 1984) revealed the presence of a $45^{\circ}$ east-dipping reverse fault crosscutting low density, subsurface sediment roughly $1 \mathrm{~km}$ west of the topographically defined range front (Depot Creek Fault: Figure 2). This fault has no surface expression and is blanketed by undeformed alluvium (WF 01: Figure 2) lithologically similar to the faulted alluvium adjacent to the Wilkatana Fault. These observations indicate that the most recent faulting event associated with the Depot Creek Fault post-dates the most recent movement on the Wilkatana Fault. We are unable to comment on previous faulting episodes during which the faults may have been linked, although the parallel trends and close proximity of the faults suggest that such a linkage is possible. Below, we describe only the Wilkatana Fault segments in detail.

\section{Northern Wilkatana Fault segments}

The incised apex of the North Wilkatana fan exposes one of the more spectacular examples of Quaternary faulting in Australia, where Neoproterozoic Emeroo Quartzite is thrust over a footwall of loosely consolidated talus breccias and river gravels of Late Pleistocene age
(Williams 1973) (Figure 3a, b). At this location, the Wilkatana Fault strikes north-northwest and dips $\sim 46^{\circ}$ to the east-northeast (Table 1; Figure 3a inset). Slickenlines are locally present in the hangingwall quartzite and indicate the latest movement involved reverse left-lateral displacement, with a slip-azimuth of $113^{\circ}$ (Table 1). Steeply dipping, north-striking subsidiary reverse faults splay off the main fault and offset the hangingwall (Figure 3a). A 0.05-0.3-m-thick layer of weathered, reddish-white carbonate-rich material lines the main fault plane (Figure $3 b$ ).

The footwall deposits are composed of conglomerates and talus breccias of the Pooraka Formation (Williams 1973). The basal talus breccia is overlain by dark-red weathered, poorly sorted coarse fluvial conglomerate with a sandy matrix (Pooraka Formation conglomerate I). This faulted conglomerate is in turn overlain by a dark-brown weathered, carbonate rich conglomerate (Pooraka Formation conglomerate II) that drapes the fault exposure and consequently post-dates the most recent slip event (Figure 3). The base of this unit is associated with a lag deposit, where coarse material consisting of rounded cobbles and boulders up to $0.4 \mathrm{~m}$ diameter has been preferentially deposited at the weathered, but intact, fault scarp (Figure 3a).

We considered three possible movement histories for this segment of the Wilkatana Fault: (i) displacement of the entire exposed footwall section (Pooraka Formation talus breccia and Pooraka Formation conglomerate I) in a single event, generating $\geq 14.9 \mathrm{~m}$ of reverse-oblique slip and $\mathrm{a} \geq 8.0 \mathrm{~m}$ high scarp; (ii) a two-event displacement history involving at least one older rupture event that displaced the talus breccia unit $\geq 8.3$ (if purely dip slip) to $11.1 \mathrm{~m}$ (if oblique slip consistent with the observed slickenlines), and a younger event involving $\geq 3.8 \mathrm{~m}$ displacement of the Pooraka Formation conglomerate I (oblique slip consistent with observed slickenlines), generating scarps of $\sim 6.0$ and $2.0 \mathrm{~m}$, respectively; and (iii) incremental displacement of the footwall section during a series of smaller magnitude earthquakes of unknown slip.

The first scenario is considered unlikely given that the earthquake magnitude required to generate the measured displacement and scarp height would be implausibly high, and would require a rupture length much longer than that observed, even when compared with the largest historic earthquakes recorded in intraplate and plate-boundary settings (Wells \& Coppersmith 1994). The second scenario is our favoured interpretation because of the observation that the post-faulting lag deposits of Pooraka Formation conglomerate II do not contain any trace of Pooraka Formation talus breccia-type angular clasts. This suggests that all talus material had been stripped from the adjacent hangingwall block prior to deposition of Pooraka Formation conglomerate II, which appears to pass vertically into faulted Pooraka Formation conglomerate I without any unconformities, implying that faulting, uplift and erosional stripping of the talus breccia occurred prior to the most recent faulting event. We cannot dismiss that the earlier event may have actually involved a series of ruptures (scenario iii), although we failed to recognise any stratigraphic or structural evidence to 
support this. We recognise that our displacement/event estimates would be decreased, and earthquake recurrence times would be increased (see below) if this was the case.

A series of north-northwest-trending, reverse-oblique fault segments with similar orientations, kinematic indicators and fault-gouge-style to the previously described fault are spaced at $\sim 5-10 \mathrm{~m}$ intervals up the North Wilkatana stream bed (Figure 2). While Quaternary slip cannot be absolutely demonstrated for most of these faults, the steeply northeast-dipping Knickpoint Fault segment $\left(32^{\circ} 06^{\prime} 55^{\prime \prime} \mathrm{S}, 137^{\circ} 57^{\prime} 26^{\prime \prime} \mathrm{E}\right)$ is located at a 4.1-m-high knickpoint in homogeneous quartzite bedrock where the fault cuts North Wilkatana creek (Figure 3c, d). South of the creek, it bifurcates upward into three splays with reverse right-lateral oblique-sense displacement, a fault geometry typical of many transpressional fault systems (Sylvester \& Smith 1976; Mandl 1988; Klepeis et al. 2002). This upward splaying geometry may provide local evidence that the Wilkatana Fault segments merge into a single fault at depth. The base of the knickpoint is located at the point where the stream bed meets the fault plane, while the top of the knickpoint has retreated some $3.0 \mathrm{~m}$ upstream from the projected fault trace and contains an incised U-shaped erosional channel of $\sim 0.3 \mathrm{~m}$ depth (Figure $3 \mathrm{c}, \mathrm{d}$ ). As identical quartzite bedrock composes both the hangingwall and footwall of the fault, we interpret the knickpoint to reflect tectonic displacement of the creek bed, rather than lithologic variability.

\section{Southern Wilkatana Fault segments}

Four segments of the Wilkatana Fault are exposed in the South Wilkatana catchment. The southern segment of the Wilkatana Fault (Figure 3e, f) is exposed on the north side of a meander bend in South Wilkatana creek, at a point where the river valley narrows markedly $\left(32^{\circ} 09^{\prime} 03^{\prime \prime} \mathrm{S}\right.$, $\left.137^{\circ} 56^{\prime} 53^{\prime \prime} \mathrm{E}\right)$. Hangingwall Emeroo Quartzite is thrust over moderately consolidated, dark-brown weathered fluvial conglomerate and underlying quartzite along a northstriking, east-dipping fault impregnated with calcareous material. Although slickenlines were not observed, we infer reverse movement as would be expected from eastwest compression and measured the dip-slip offset as $6.1 \mathrm{~m}$. As is the case for the northern segment of the Wilkatana Fault, we are unable to absolutely resolve whether this minimum fault displacement reflects one or multiple rupture events. Given the lack of stratigraphic evidence to the contrary, we infer that this scarp resulted from a single large event. In support of this assertion, a $6 \mathrm{~m}$-high bedrock knickpoint in the stream profile, contained within Emeroo Quartzite, is located $\sim 20 \mathrm{~m}$ upstream of the fault (Figure 3e, f). A vertically incised, narrow river valley is present between the knickpoint and the fault, implying rapid, post-faulting incision. Downstream of the fault, the valley form is broad and U-shaped. We infer that the knickpoint resulted from a single faulting event, analogous to the history described for the Knickpoint Fault segment to the north. Intriguingly, two poorly exposed reverse faults branch from the master fault near river level and offset conglomeratic valley-fill and underlying, weathered quartzite bedrock in the footwall (Figure 3e, f). Although the limited exposure precluded an estimation of fault offset, these faults may represent additional rupture events, consistent with the multiple events recognised to the north.

The fourth fault segment (Cobble Fault segment) is located $\sim 200 \mathrm{~m}$ west of the previously described segments $\left(32^{\circ} 09^{\prime} 05^{\prime \prime} \mathrm{S}, 137^{\circ} 56^{\prime} 50^{\prime \prime} \mathrm{E}\right)$ and offsets carbonatecemented fluvial conglomerates by $\sim 0.3 \mathrm{~m}$ along a north-striking, steeply dipping fault plane. Both the Cobble and southern Wilkatana Fault segments trend toward the range front, where they are buried beneath hillslope alluvium.

\section{BURRA FAULT}

The Burra Fault (Figure 3g, h) is exposed in a steeply incised gully at Worlds End Creek $\sim 5 \mathrm{~km}$ east of the main topographic front of the central Flinders Ranges $\left(33^{\circ} 45^{\prime} 28^{\prime \prime} \mathrm{S}, 139^{\circ} 05^{\prime} 39^{\prime \prime} \mathrm{E}\right)$. This bedding-parallel structure strikes north-northwest, dips moderately southwest, and contains traces of poorly developed dip-slip slickenlines along the sinuous fault plane (Table 1; Figure $3 \mathrm{~g}$ inset). The exposed dip-slip offset is $3.8 \mathrm{~m}$. Northweststriking, subvertical extensional fractures are present throughout the hangingwall, probably related to collapse shortly after reverse faulting. A lag deposit of coarse, weathered bedrock material is present at the base of the hangingwall, implying that the rupture generated a surface scarp that persisted until burial by Pooraka Formation colluvium (Figure 3g). At present, there is no surficial expression of the fault. The hangingwall consists of deeply weathered siltstones and tillites of the Neoproterozoic Appila Tillite (W. V. Preiss pers. comm. 2003). The footwall deposits consist of fine-grained, red-weathered alluvium incised by small pebbly and sandy fluvial channels, with varying amounts of soil carbonate. This sequence is capped by a 0.4-m-thick soil horizon. We infer a single rupture event for this locality.

\section{MUNDI MUNDI FAULT}

The Mundi Mundi Fault is exposed at the base of the western scarp front of the Barrier Ranges (Figure 1) on the north and south banks of the first drainage south of Umberumberka Creek ( $\left.31^{\circ} 49^{\prime} 05^{\prime \prime} \mathrm{S}, 141^{\circ} 12^{\prime} 14^{\prime \prime} \mathrm{E}\right)$. The fault is located $\sim 50 \mathrm{~m}$ downstream of the Umberumberka Dam and Reservoir and has been exposed, in part, due to fluvial diversion and reservoir overflow during the building of the dam. The range-front fault strikes north, dips at $48^{\circ}$ east (Table 1 ; Figure $3 \mathrm{i}$ inset), and contains well-developed, east-plunging, dip-slip slickenlines on brecciated clasts within the fault zone. The fault zone is $\sim 0.25 \mathrm{~m}$ thick and consists of strongly altered hangingwall schist and footwall gravel clasts in a fine-grained, grey-green clayey matrix (Figure $3 \mathrm{i}, \mathrm{j}$ ). The exposed dipslip offset of alluvial gravels (Pooraka Formation I) is $2.1 \mathrm{~m}$.

West-dipping normal faults at the toe of the hangingwall imply post-faulting collapse of the surface scarp. A basinward-widening wedge of colluvium (Pooraka Formation II) consisting of coarse, angular bedrock 

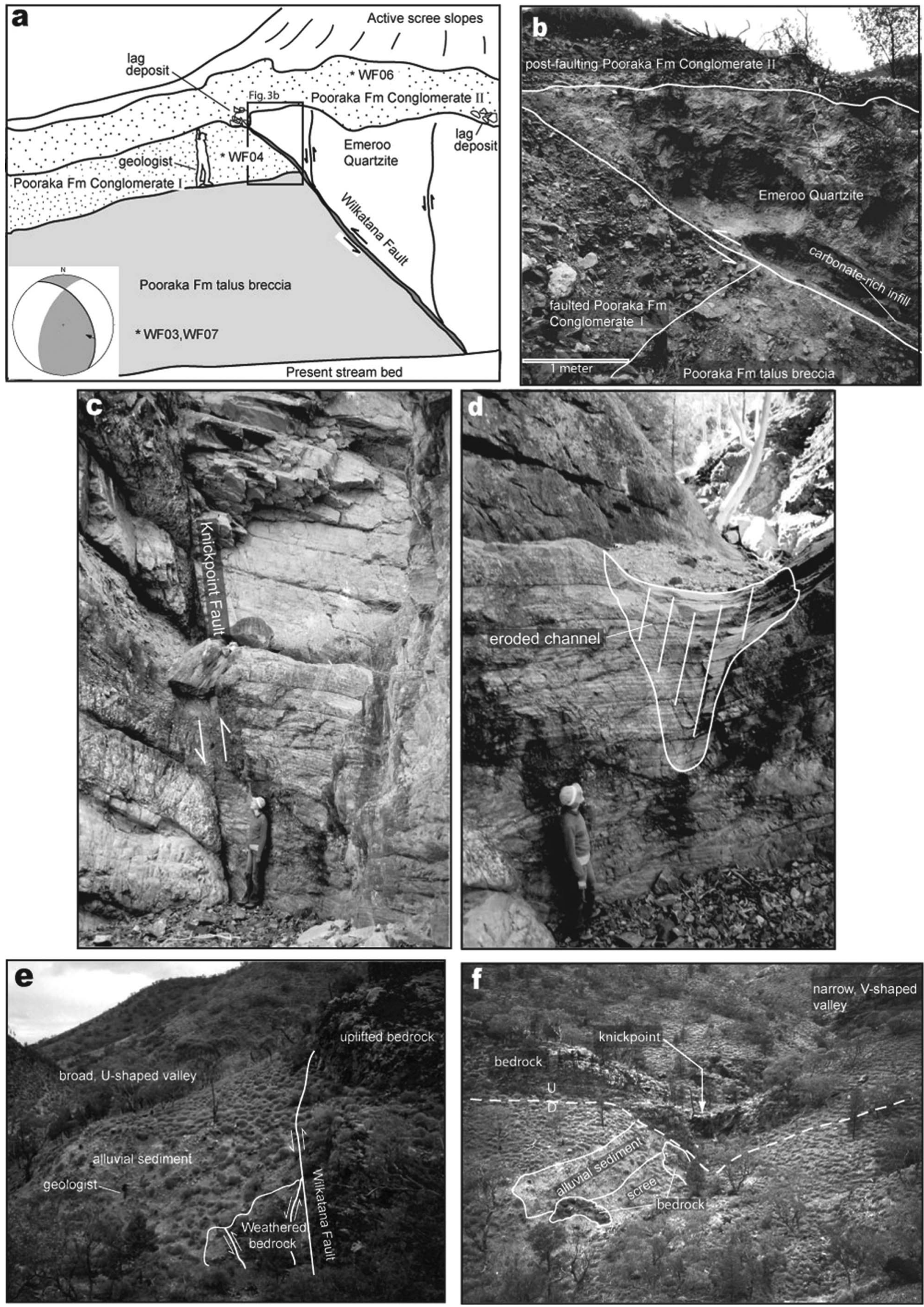

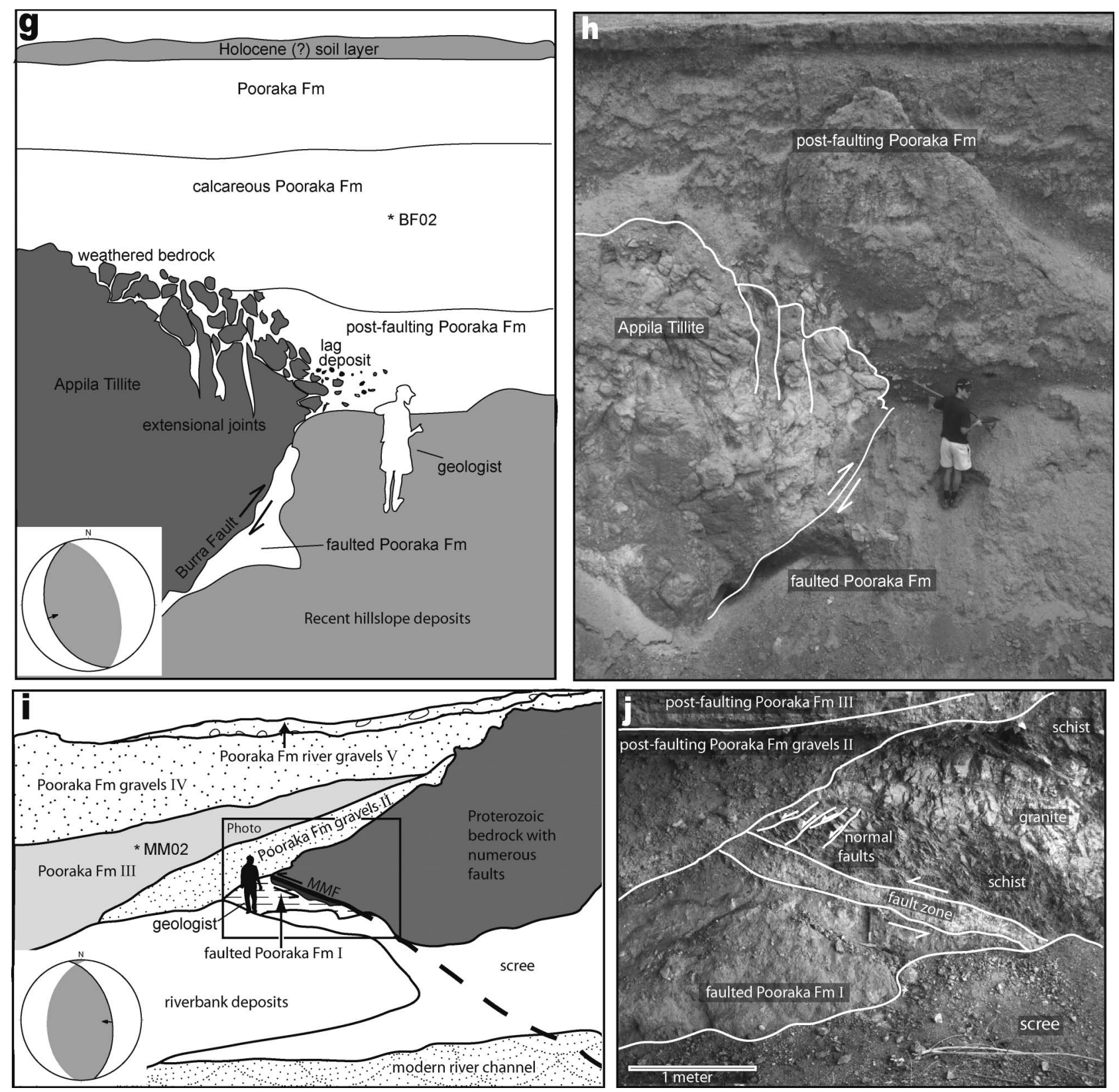

Figure 3 Geologic cross-sectional sketch maps and field photographs. (a, b) Northern segment of the Wilkatana Fault

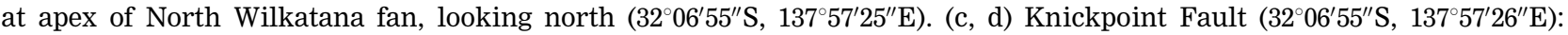
(c) Knickpoint Fault and associated hangingwall knickpoint, looking north-northeast, creek flows from right to left; (d) Hangingwall knickpoint across Knickpoint Fault, looking east (upstream) at U-shaped channel incised into uplifted bedrock. (e, f) Southern segment of the Wilkatana Fault, looking north-northwest (e) and looking east (f) (32 $09^{\prime} 03^{\prime \prime} S$, $\left.137^{\circ} 56^{\prime} 53^{\prime \prime} \mathrm{E}\right)$. (g, h) Burra Fault, looking north $\left(33^{\circ} 45^{\prime} 28^{\prime \prime} \mathrm{S}, 139^{\circ} 05^{\prime} 39^{\prime \prime} \mathrm{E}\right)$. (i, j) Mundi Mundi Fault, looking north $\left(31^{\circ} 49^{\prime} 05^{\prime \prime} \mathrm{S}\right.$, $\left.141^{\circ} 12^{\prime} 14^{\prime \prime} \mathrm{E}\right)$. See text for details. Locations of OSL samples (Table 2) shown. Height of geologist roughly $180 \mathrm{~cm}$. Earthquake focal mechanism solutions (Fowler 1990) appear in lower left insets. Compressive dihedral in grey, fault plane in bold, and slip vector marked on the fault plane with small arrow.

material derived from the hangingwall indicates hillslope burial of the footwall and removal of associated surface relief occurred relatively soon (up to thousands of years: Crone et al. 2003) after faulting.

The hangingwall consists of pervasively fractured pelitic and semipelitic schists of the Early Palaeoproterozoic Willyama Supergroup (Stevens 1980; Stevens \& Corbett 1993) intruded by Mesoproterozoic granites and pegmatites. The schist immediately above the fault contact is strongly folded and faulted, suggesting that the deformation zone may be $2-3 \mathrm{~m}$ in width. The footwall consists of a $1 \mathrm{~m}$-thick poorly stratified, moderately consolidated clay-rich deposit (Pooraka Formation I), which is weathered dark-red and contains subangular granite clasts derived from the hangingwall. Clasts from the schist are absent, suggesting that schist may not have been aerially exposed on the adjacent hillslope during deposition of this unit, perhaps due to increased 
weathering of the schist material. The immediate overlying post-faulting deposits consist of hillslope deposits comprising a mix of coarse, angular schist and granite clasts in a dark-red sandy matrix. The wedge-shaped basal unit consists of large, unweathered, angular blocks of schist suspended in the gravelly matrix (Pooraka Formation II). This unit is overlain by a $\sim 1 \mathrm{~m}$-thick, sandy matrix-supported, deposit (Pooraka Formation III) followed by a $\sim 2.5 \mathrm{~m}$-thick unit with a similar matrix containing abundant granite clasts (Pooraka Formation IV). A $<0.4$ m-thick, clast-supported gravel containing various rock types caps the sequence (Pooraka Formation V) and is lithologically similar to the present stream bed.

A series of north- to northeast-striking faults with an orientation similar to the range-front fault occurs throughout the exposed bedrock section at $10-20 \mathrm{~m}$ intervals, beginning some $10 \mathrm{~m}$ east of the Mundi Mundi Fault. Although no unambiguous evidence for Quaternary slip can be found on these structures, the similarity in attitude with the Mundi Mundi Fault indicates that they may also have slipped during the Mundi Mundi event, thus comprising a distributed zone of faults. The parallelism of the Mundi Mundi Fault with these structures, as well as ductile shear zones which deform this sequence, suggests that older tectonic structures may have influenced the geometry of Quaternary faults (Gibson et al. 1997). Hill and Kohn (1999) described a series of offset terraces and fans to the north of this locality, providing further evidence for neotectonic activity in this region.

\section{TIMING OF FAULTING FROM OPTICALLY STIMULATED LUMINESCENCE DATING}

The stratigraphic relationship of the fault-related sediments described above is of utmost importance to determining the timing and displacement of fault movements. Williams (1973) attempted to date carbonised wood from deposits equivalent to the Pooraka Formation exposed in the footwall of the northern Wilkatana Fault segment using traditional ${ }^{14} \mathrm{C}$ methods. His ages of $>38 \mathrm{ky} \mathrm{BP}(>42.5 \mathrm{ka})$ and $c a 33 \mathrm{ky} \mathrm{BP}$ ( $c a 37.5 \mathrm{ka})$ approach the limit of the ${ }^{14} \mathrm{C}$ technique and thus may be regarded as providing minimum age bounds only. Soil carbonates within the palaeosol that caps the Pooraka Formation (Wilkatana palaeosol) yielded radiocarbon ages in the range $30-20 \mathrm{ky} \mathrm{BP}(35-24 \mathrm{ka})$ (Williams 1973).

Williams (1973) obtained a ${ }^{14} \mathrm{C}$ age of $23.5 \mathrm{ky} \mathrm{BP}$ ( $c a$ $27.5 \mathrm{ka}$ ) from carbonate-rich material lining the northern segment of the Wilkatana fault plane. Williams (1973) interpreted this material as undeformed carbonate precipitate, thus constraining the timing of faulting to $>27.5 \mathrm{ka}$. However, our own thin-section observation of this material revealed complexly mixed carbonate textures, and we are accordingly cautious about the interpretation of this result.

Luminescence dating has proven to be an effective technique for estimating the depositional age of Late Quaternary sediments and is applicable over longer time intervals ( $\leq 800000$ years) than conventional 
radiocarbon dating (Aitken 1998). However, datable maximum age limits are highly dependent on the composition of the sample, with upper age limits in the Flinders Ranges confined to 100-80 ka. Dating of alluvial deposits, which may contain sediments of different exposure ages, has recently been aided by the emergence of new luminescence methodologies allowing the effective dating of single grains of quartz (Olley et al. 2004). We used single grain optically stimulated luminescence dating to attempt to quantify the age of surface rupture events associated with each of the sites described in the previous section.

\section{Optically stimulated luminescence methods}

Optically stimulated luminescence (OSL) samples were collected by driving $50 \mathrm{~mm}$-diameter stainless-steel tubes into cleaned sections through representative sedimentary sequences. Five samples were collected from the Wilkatana area, with one each from the Worlds End Creek and Umberumberka Creek localities. Sediments were processed under subdued red light, with the 90-125 $\mu \mathrm{m}$ quartz fraction extracted for dating using standard procedures (Galbraith et al. 1999).

A single aliquot regenerative dose protocol was used to calculate equivalent doses $\left(D_{\mathrm{e}}\right)$ (Murray \& Roberts 1998; Galbraith et al. 1999; Murray \& Wintle 2000). Approximately 100 aliquots per sample, each composed of single grains of quartz, were preheated at $240-260^{\circ} \mathrm{C}$ for $10 \mathrm{~s}$ and optically stimulated for $2 \mathrm{~s}$ at $125^{\circ} \mathrm{C}$ by green (532 nm) light from a solid-state laser beam attached to an automated Risø TL-DA-15 apparatus. Ultraviolet luminescence was detected using a photomultiplier tube with a $7.5 \mathrm{~mm}$ U-340 filter. Samples were then given applied doses using a calibrated ${ }^{90} \mathrm{Sr} /{ }^{90} \mathrm{Y}$ beta-source and restimulated to record their regenerative OSL signals. OSL sensitivity changes in the quartz crystals between the natural and regenerative cycles were monitored after each optical stimulation using testdoses of $10 \mathrm{~Gy}$ following a $160^{\circ} \mathrm{C}$ cut-heat.

Output from the Risø apparatus was analysed using Analyst version 2.12 software (Duller 1999). OSL signals were measured for $2 \mathrm{~s}(100 \times 0.02 \mathrm{~s}$ channels $)$ with data integrated from the five channels 5-9. Integrated data from channels 80-90 were converted to the equivalent signal from five channels and used as background. The OSL data were corrected for any sensitivity changes and dose-response curves constructed using six or seven regenerative dose points. $D_{\mathrm{e}}$ values were obtained from the intercept of the regenerated dose-response curve with the natural luminescence intensity. $D_{\mathrm{e}}$ values for aliquots in each sample typically displayed normal frequency distributions, suggesting that significant incursions of grains younger than the burial event or incomplete resetting of luminescent signals prior to deposition had not occurred. Thus, optical ages were derived from weighted mean $D_{\mathrm{e}}$ using the central age model of Galbraith et al. (1999).

Preheat tests were carried out by holding three aliquots of $\sim 100$ grains from each sample for $10 \mathrm{~s}$ at one of four preheat temperatures over the range $160-$ $280^{\circ} \mathrm{C}$. The resultant flat plateaux indicated negligible thermal transfer in the samples. Recuperation tests also showed that the samples displayed no significant radiative recombination. These experiments, including recycling tests using duplicate regenerations of known dose, confirmed the reproducibility of the laboratoryinduced luminescence signals.

$\mathrm{K}, \mathrm{U}$ and Th concentrations were measured using instrumental neutron activation analysis (INAA) by Becquerel Laboratories, Menai, New South Wales and Mississauga, Ontario and converted to beta dose rates using the conversion factors of Adamiec and Aitken (1998). A beta attenuation factor of $0.93 \pm 0.03$ (Mejdahl 1979) was assumed. Gamma dose rates were measured in the field using a portable spectrometer and converted to dry values by oven-drying sediment from the sample location. Internal alpha dose rates were also assumed to be $0.03 \pm 0.01 \mathrm{~Gy} / 10^{3} \mathrm{y}$ based on previous measurements of Australian quartz (Thorne et al. 1999; Bowler et al. 2003).

Cosmic-ray dose rates were determined from established equations (Prescott \& Hutton 1994), allowing for sample depth, sediment density and site altitude and latitude. Present-day field-moisture contents of the sediments were considered broadly representative of long-term averages and used to correct attenuation of beta and gamma rays by water (Aitken 1998).

\section{Optically stimulated luminescence results}

OSL sample locations are shown in Figures 2 and 3, with the results of the analyses including optical age determinations displayed in Table 2. Timing constraints on the Wilkatana, Burra and Mundi Mundi Faults are summarised in Table 1.

Northern Wilkatana Fault segment samples WF03 and WF07 were obtained from alluvial sand and gravel lenses intercalated with debris flows of subangular quartzite pebble, cobble and boulder clasts. These debris-flow deposits are correlative with the breccias exposed in the footwall of the northern Wilkatana Fault segment (Figure 3a), about $100 \mathrm{~m}$ upstream, and have been assigned to the Pooraka Formation (Williams 1973). The Pooraka Formation was not sampled directly at the base of the fault as it seems unlikely that that this massflow deposit received sufficient sunlight to empty the electron traps (i.e. the samples were not 'zeroed' prior to deposition). Samples WF03 and WF07 yielded optical ages suggesting deposition of this section of the Pooraka Formation at $c a 60 \mathrm{ka}$ (Table 2).

Sample WF04 was obtained from the Pooraka Formation fluvial conglomerate overlying the talus breccias in the footwall of the main reverse fault and yielded an optical age of $c a 32$ ka (Table 2) providing a maximum age for the last movement of the northern Wilkatana Fault segment. The footwall gravels and hangingwall Emeroo Quartzite are truncated by erosion about $1 \mathrm{~m}$ above sample WF04, above which occur distinctive terraced alluvial gravels. Sample WF06 was collected in this unit on the southern side of the stream from a depth of $0.3 \mathrm{~m}$ and yielded an optical age of $c a 29 \mathrm{ka}$ (Table 2), providing a minimum age of faulting and effectively bracketing the age of the last movement on the northern Wilkatana Fault segment to the $c a 32-29$ ka interval. 
Sample WF01 came from Pooraka Formation alluvial gravels immediately overlying the subsurface location of the Wilkatana Fault at Depot Creek, as indicated by Preiss and Faulkner (1984). This unit is undisturbed by faulting, and its optical age of $c a 71$ ka provides a minimum time frame over which this portion of the Wilkatana Fault has remained inactive. These results complement the geomorphic evidence described above and indicate that this portion of the Wilkatana Fault was inactive during post-ca $71 \mathrm{ka}$ faulting in the northern Wilkatana Fault segment.

BF02 was obtained at the Burra Fault locality from a coarse sand and gravel bed in a fluvial channel sequence assigned to the Pooraka Formation (W. V. Preiss pers. comm. 2003). This unit overlies faulted gravels in the footwall of the Burra Fault and yielded an optical age of ca $83 \mathrm{ka}$ (Table 2), placing a minimum age constraint on the most recent surface-rupturing movement. Dating of the underlying faulted deposits by OSL is not possible due to the high local environmental dose rates, which saturate the luminescent traps in samples older than around $100 \mathrm{ka}$.

Similarly, the Mundi Mundi sediments have high environmental dose rates, restricting the usefulness of OSL. The luminescence signal of quartz in the uppermost unit was saturated. This sample (MM02) from channel-fill deposits above the Mundi Mundi Fault yielded a minimum age of $>53 \mathrm{ka}$, providing a minimum age constraint for the most recent surface rupture.

\section{TIMING OF FAULTING FROM KNICKPOINT RETREAT}

Previously, we described the rationale behind our interpretation that bedrock knickpoints in the northern and southern Wilkatana catchments formed in response to recent faulting. Semi-empirical constraints on the timing of faulting can be obtained by hypothesising the likely geomorphic response of the knickpoints to fluvial incision subsequent to their genesis. For the Knickpoint Fault, we measured the horizontal distance from the centre of the U-shaped erosional channel incised in the hangingwall to the downstream projection of the fault plane, and thus inferred that $3.0 \mathrm{~m}$ of horizontal bedrock retreat occurred subsequent to fault-induced knickpoint genesis. We divided this value by a linear knickpoint retreat rate of $250-500 \mathrm{~m} / 10^{6} \mathrm{y}$, established for a bedrock-floored channel draining an equivalent sized, lithologically similar catchment in the arid Dead Sea region (Haviv et al. 2003), to determine the time lapsed since knickpoint genesis (12-6 ka). Although minimal work has been done on knickpoint retreat rates, preliminary results suggest that retreat velocity is strongly controlled by catchment area and climate, justifying our choice of this relatively low retreat rate. Estimated knickpoint retreat rates in other semiarid regions are one to two orders of magnitude higher (Nott et al. 1996; van der Beek et al. 2001; Phillips et al. 2003) suggesting that our estimation for the timing of faulting at $\leq 12$ ka may be interpreted as a maximum age (Table 1). We applied the same technique and 
retreat rates to the southern Wilkatana catchment, where the knickpoint lies $20.0 \mathrm{~m}$ upstream of the fault plane, to estimate the timing of the southern Wilkatana knickpoint to be $\leq 80 \mathrm{ka}$. These data, while subject to our field interpretations and assumed retreat rate, are consistent with our earlier field-based assertions that the southern segment of the Wilkatana Fault may have ruptured synchronously with the northern segment during a single large event.

\section{CALCULATION OF FAULT-SLIP RATES}

We determined Pliocene-Holocene fault-slip rates for the Wilkatana, Burra and Mundi Mundi Faults in order to provide bounding constraints on long-term fault behaviour and cumulative displacement since $c a 5 \mathrm{Ma}$. The ca $5 \mathrm{Ma}$ interval was chosen because it is thought to reflect the time in which this region began deforming in a manner consistent with the contemporary intracontinental in situ stress field derived from plate-boundary forces (see above), and also approximately corresponds to the change in the Torrens Basin stratigraphy from finer grained calcareous muds and shales (Alley \& Benbow 1995) to coarser sandy muds and gravels (Callen et al. 1995). Minimum fault slip rates $\left(\mathrm{FSR}_{\min }\right.$, Table 1$)$ were calculated for the Wilkatana Fault using estimated thicknesses of Pliocene-Holocene footwall sediment (Table 1) that has accumulated in the Wilkatana alluvial fans. Thickness estimates were based on general lithologic descriptions of two Santos drillholes which recorded a transition from coarser gravels to finer shales with depth (Wilkatana 1, 2: A. Smart pers. comm. 2003). Our inferred thicknesses of Pliocene and Quaternary sediment are consistent with the 80-105 m-thick low-density layer modelled from beneath the Depot Creek fan surface using gravity data (Preiss \& Faulkner 1984). The Mundi Mundi Fault footwall depths were estimated from seismic data (Gibson et al. 1997). We corrected our vertical thickness estimates for fault dip to determine the total displacement of Pliocene and Quaternary strata and divided this value by 5 Ma to determine FSR $_{\text {min }}$ (Table 1).

Because hangingwall erosion was not considered, $\mathrm{FSR}_{\text {min }}$ is likely to underestimate total fault-slip rates and thus represent absolute minimum rates. FSR $_{\text {min }}$ was not estimated for the Burra, Cobble and Knickpoint Faults, where no constraints could be placed on fault offsets.

In order to incorporate the effects of hangingwall erosion into our fault-slip analysis, we estimated the present elevation of the uplifted $c a 5$ Ma Flinders Ranges land surface, based on regional geomorphological (Tokarev et al. 1999) and geological (Callen \& Tedford 1976; Wellman \& Greenhalgh 1988) observations, and projected this surface to the range front (Figure 2). This surface intersects the aerial projection of the Wilkatana Fault at an elevation of $\sim 90 \mathrm{~m}$ above the present erosional surface, while the inferred Barrier Ranges land surface intersects the projected Mundi Mundi Fault at $\sim 80 \mathrm{~m}$ above the top of the present Mundi Mundi Plain. Extrapolated fault-slip rates $\left(\mathrm{FSR}_{\text {ext }}\right)$ determined using this method incorporate the footwall sedimentary thicknesses described above and eroded hangingwall thicknesses (Table 1). FSR ext results are comparable to other long-term fault-slip rates established in the Flinders Ranges $\left(20-150 \mathrm{~m} / 10^{6}\right.$ y: Sandiford 2003) and other stable continental regions (Crone \& Luza 1990; Crone et al. 1997).

\section{CALCULATION OF MOMENT MAGNITUDE}

In order to investigate the moment magnitude (M) associated with the described faulting events, we utilised the geological data acquired from the fault exposures and estimated the $\mathbf{M}$ required to generate these features. We used two methods to determine $\mathbf{M}$. Where we were able to determine both the fault displacement and rupture length for a given fault (Wilkatana and Mundi Mundi Fault), we used the Hanks and Kanamori (1979) relationship to calculate the seismic moment $M_{\mathrm{O}}$ and moment magnitude:

$$
\begin{gathered}
M_{\mathrm{O}}=\mu \times R A \times D \\
\mathbf{M}=2 / 3 \log M_{\mathrm{O}}-10.7,
\end{gathered}
$$

where $\mu$ is the shear modulus of elasticity $\left(3 \times 10^{11}\right.$ dyne/ $\mathrm{cm}^{2}$ : Hanks \& Kanamori 1979), $R A$ is the area of the fault that ruptured (the product of the surface rupture length $S R L$ and downdip rupture width $R W$ ), and $D$ is the average displacement across the fault surface.

In order to determine $R A$ for the Wilkatana Fault, we inferred lateral continuity between the northern and southern segments on the basis of the geological field observations and ASTER satellite-image interpretation noted above, and measured a $S R L$ of $13.8 \mathrm{~km}$ using the ENVI $^{\mathrm{TM}}$ computer program (Figure 2). Although we were not able to directly identify synchronous events in the two segments, we noted the probability that the three rupture events described for the northern segments may correspond to the three events described for the southern segment (excluding the Cobble Fault segment event). To this end, we assumed that our estimated $S R L$ is somewhat representative of average rupture lengths involving this fault system, and applied this value to the recognised events in the northern and southern segments. Although this is undoubtedly a simplification, it is the most robust reporting of $S R L$ we could provide for this region.

For the Mundi Mundi Fault, we inferred a $S R L$ of 29.0 $\mathrm{km}$ coincident with a major, low-sinuosity, northnortheast-striking escarpment developed between Umberumberka and Cartwrights Creeks, as indicated from field investigations (Hill \& Kohn 1999; this study) and ASTER satellite-data interpretation. The absence of any surface expression attributable to the Burra Fault precluded the use of this method, as we were unable to determine $S R L$ from field measurements.

To determine $R W$ for both the Wilkatana and Mundi Mundi Faults, we extrapolated surface fault orientations to the range of seismogenic depths characteristic of Flinders Ranges earthquakes. Earthquake hypocentral calculations suggest that $80 \%$ of the Flinders earthquakes are located within the upper crust at depths of $<20 \mathrm{~km}$, 
with a median depth for the central Flinders Ranges of 9.3 $\mathrm{km}$ (Greenhalgh et al. 1986, 1994). Intriguingly, two of the larger Australian earthquakes, the $1968 \mathrm{M}_{\mathrm{S}} 6.8$ Meckering event and the $\mathrm{M}_{\mathrm{S}}$ 6.3-6.7 Tennant Creek events, have calculated hypocentral depths of $\leq 6 \mathrm{~km}$ (Langston 1987; Bowman \& Dewey 1991). We thus assumed a preferred hypocentral depth range for surface-rupturing events of 6-20 km (preferred range, Figure 4), while acknowledging the possibility of shallower or deeper foci. We used this range of hypocentral depths to calculate $R W$ for the Wilkatana Fault by inferring an average fault dip of $66^{\circ}$ (averaged from surface measurements of northern and southern Wilkatana Fault segment planes) resulting in a range of $R W$ from 6.9 to $23.1 \mathrm{~km}$. We used a dip of $48^{\circ}$ for the Mundi Mundi Fault, resulting in $R W$ estimates of $8.1-26.9 \mathrm{~km}$.

Finally, we used our field measurements of fault displacements and assumed that they represent an average displacement $(D)$ of the fault during a single rupture event.

Estimates of $\mathbf{M}$ vs hypocentral rupture depth for segments of the Wilkatana Fault and Mundi Mundi Faults appear in Figure 4. Earthquake moment magnitudes required to generate the observed surface rupturing faults range from 6.3 to 7.4, depending on rupture depth. Although we think it is likely that the southern Wilkatana segments ruptured synchronously with the northern segments, we estimated $\mathbf{M}$ for the largest southern segment (Figure 3e, f) to provide additional constraints on the Wilkatana Fault. Preferred values for the Wilkatana Fault in the North and South Wilkatana areas, including the Knickpoint Fault, range from 6.6 to 7.3. Preferred values for the Mundi Mundi Fault range from 6.9 to 7.3 .

We also estimated $\mathbf{M}$ for the Wilkatana, Burra and Mundi Mundi Faults using the Wells and Coppersmith (1994) statistical relationship between $\mathbf{M}$ and SRL determined for historical earthquakes:

$$
\mathbf{M}=a+b \log (S R L)
$$

where $a=5.00$ and $b=1.22$ are empirically determined parameters based on a large historical dataset. For the Burra Fault, where $S R L$ is unknown, we first used the relationship (Wells \& Coppersmith 1994)

$$
\log (S R L)=a+b \log (D)
$$

where $a=1.45, b=0.26$ and $D$ was measured in the field to be $3.8 \mathrm{~m}$ (Table 1 ) to determine $S R L$, and then applied the previous formula to determine M. Our results appear in Table 1. Clark and McCue (2003) estimated an $\mathbf{M}>6.2$ earthquake for the Wilkatana Fault using this method, although they used an $S R L$ of $10 \mathrm{~km}$ in their calculation.

Moment magnitudes determined from this method are generally lower than those determined from the Hanks and Kanamori (1979) method but are within the range of extrapolated values using that method. Given the potential for rapid removal of scarp length due to burial, as observed at all of these exposures, and rapid scarp degeneration (Clark \& McCue 2003), we suggest that our SRLs for the Wilkatana Fault provide minimum bounds on the earthquake moment magnitudes that generated these features.

\section{CALCULATION OF RECURRENCE INTERVAL}

We used two methods to estimate earthquake recurrence intervals for the Wilkatana Fault. The first method involved treating the Northern Wilkatana, Southern Wilkatana and Knickpoint Fault segments as separate surface expressions of ruptures resulting from discrete movements along a master fault. We thus interpret at least three distinct ruptures to have occurred since $c a 67$ ka and, using the simple relationship,

Recurrence interval $=$ no. of earthquakes/time elapsed,

we estimate a recurrence interval for surface-rupturing earthquakes along the Wilkatana Fault of $\sim 22000$ years. We omitted the Cobble Fault from this analysis due to the lack of age constraint.

The second approach was to calculate a recurrence interval based on historical seismicity (Greenhalgh et al. 1986, 1994) using the recurrence (frequencymagnitude) relationship (Evernden 1970)

$$
\log _{10} N_{\mathrm{C}}=N_{\mathrm{O}}-b \mathbf{M} \text {, }
$$

where $N_{\mathrm{C}}$ is the cumulative number of earthquakes per year for a magnitude greater or equal to $\mathbf{M}$. Substituting $\mathbf{M}=0$ into this equation yields the activity parameter $N_{\mathrm{O}}$, equivalent to the number of earthquakes per year within a given region. The slope parameter $b$ of the loglinear relation represents the ratio of small to large earthquakes within a region.

Based on a regression fit of $\mathbf{M} \geq 1.4$ Flinders Ranges earthquake data from 1980 to 1992, Greenhalgh et al. (1994) calculated a recurrence relationship

$$
\log _{10} N_{\mathrm{C}}=3.75-1.04 \pm 0.09(\mathbf{M}),
$$

resulting in an average return period of 1300 years for an earthquake of $\mathbf{M} \geq 6.6$ for the Flinders Ranges. The error in the linear fitting results in recurrence intervals as high as 1:331 years and as low as 1:5105 years (Greenhalgh et al. 1994). By extrapolating the Greenhalgh et al. (1994) relationship over the Wilkatana Fault area (about $1.6 \%$ of total seismically active area of the Flinders Ranges: Figure 1), and assuming a random distribution of earthquakes throughout the Flinders Ranges area, we estimate a recurrence interval of $\sim 1: 81250$ years for $\mathbf{M} \geq 6.6$ earthquakes. We interpret this as an uppermost bound on recurrence intervals for the Wilkatana Fault because much of the seismically active area we used for the calculation does not appear to have any geomorphic expression of faulting, suggesting that seismicity may be concentrated along distinct zones such as range-bounding or pre-existing faults (Machette et al. 1993; Crone et al. 2003). In addition, the locus of strain release may be migratory in geological time, thus resulting in an inconsistency between geological and seismological recurrence intervals (D. J. Clark pers. comm. 2005).

\section{GEOMORPHIC IMPLICATIONS OF QUATERNARY FAULTING}

The Wilkatana and Mundi Mundi Faults define the prominent western margins of the Flinders and Barrier 

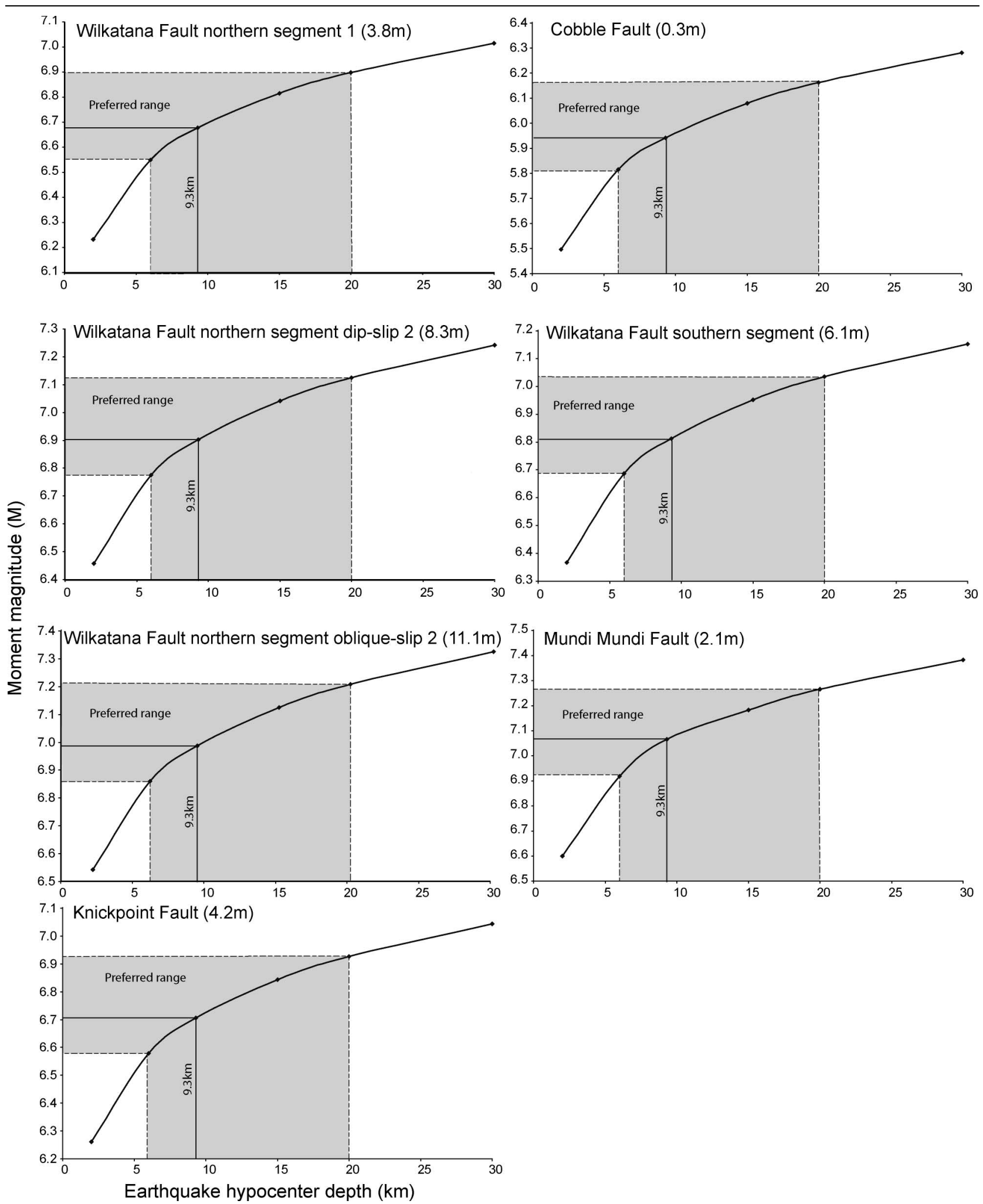

Figure 4 Moment magnitude (M) vs earthquake hypocentre depth for surface-breaking faults. M for the earliest event observed at the northern segment of the Wilkatana Fault (Wilkatana Fault northern segment 2) estimated for both dip-slip and oblique-slip scenarios. Preferred range limited to 6-20 km hypocentral depths, with mean of historical seismicity (9.3 km: Greenhalgh et al. 1994) shown.

range fronts, respectively, indicating a strong casual link between faulting and the geomorphic development of these landscapes. The Mundi Mundi range front is widely recognised as a slightly retreated fault-line escarpment (Mawson 1912; Stevens 1986; Hill \& Kohn 1999). Both range fronts are characterised by youthful geomorphology, including steep, sharply defined morphologies (Hill \& Kohn 1999), uplifted palaeosurfaces 
(Mawson 1912; Stevens 1986; Tokarev et al. 1999), valleyin-valley features (Mawson 1912; Hill \& Kohn 1999; Quigley et al. 2004), recent landslides (Quigley et al. 2004) and well-developed alluvial fans (Williams 1973; Wasson 1978).

Although influenced by climate (Williams 1973; Wasson 1978), the increased rates of Quaternary incision, evident from the rugged catchment geomorphology, and range-front sedimentation, evident from the alluvial fans, have been recognised as indicators of neotectonic activity (Hill \& Kohn 1999; Quigley et al. 2004). This interpretation is supported by our geological observations of headward propagation of fault-generated knickpoints in the North and South Wilkatana catchments, a process that has led to steeply incised landscapes elsewhere in Australia (van der Beek et al. 2001). The increasing recognition of Quaternary faults bounding rugged portions of the Flinders Ranges (Sandiford 2003) further emphasises the connection between regionally enhanced historical seismicity, neotectonics and landscape evolution.

If our estimation of the height of the domed, prePliocene planation surface in the hangingwalls of the Wilkatana and Mundi Mundi Faults is correct (used to

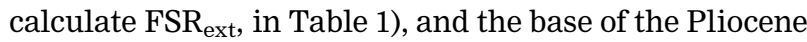
sequence in fault footwalls corresponds to this surface prior to faulting, then the amount of total vertical bedrock uplift in the hangingwalls of both faults since 5 Ma approximates to $180 \mathrm{~m}$. This is enough to account for more than $30 \%$ of the maximum elevations achieved in the central Flinders Ranges and $60 \%$ of the maximum elevations achieved in the Barrier Ranges. The results imply that the active neotectonic regime, in concert with climatic and lithologic factors, has strongly influenced parts of the Australian landscape through tectonic uplift. The continuity of these faults along the ranges remains a strong focal point for future study.

The ability of these faults to influence the evolution of a landscape well within the interior of a supposedly stable continent is profound, particularly given the lack of a persistent geomorphic signature associated with some stable continental region faults (Crone et al. 1997, 2003). The long recurrence intervals (>100000 years) and low long-term slip rates that typify some stable continental region faults, combined with rapid scarp degeneration (e.g. $0.3 \mathrm{~m}$ over 14 years at the Marryat Creek Scarp: Clark \& McCue 2003; also see Crone et al. 1992) and burial by aeolian or alluvial processes common in deep-weathering arid regions and/or areas susceptible to anthropogenic influence, result in subtle to unidentifiable geomorphic expressions for many of these structures. The Burra Fault is testimony to this process, in that it lacks any surficial expression, displays evidence for rapid weathering and scarp burial (Figure 3g, h), and would not have been detectable had it not been incised by the gully at Worlds End Creek.

\section{DISCUSSION}

The Wilkatana, Burra and Mundi Mundi Faults form part of an increasing body of evidence for large $\mathbf{M}$ palaeo-earthquakes preserved in the Quaternary neotectonic record of southern Australia. The orientation of maximum principle palaeostresses (Figure 5), derived from field measurements of fault orientations and slickenlines, indicates that individual fault displacements occurred in response to approximately eastwest-directed horizontal compressive stress $\left(\mathrm{SH}_{\mathrm{Max}}\right)$ consistent with the $\mathrm{SH}_{\mathrm{Max}}$ derived from focal mechanisms of historical earthquakes (Clark \& Leonard 2003). The correlation between historical seismicity and the Quaternary faulting record implies that much can be learned about the current geodynamic state of the Australian Plate from neotectonic studies of these structures, including seismic risk and the evolution of Australian landscapes (Sandiford 2003).

The faults share some characteristics with wellstudied, typical intraplate faults from stable continental regions (Crone \& Luza 1990; Machette et al. 1993; Crone et al. 1997, 2003). The Mundi Mundi Fault parallels a network of Proterozoic ductile and brittle structures (Stevens 1986; Gibson et al. 1997), while the Burra Fault parallels bedding planes and lithological contacts, suggesting Quaternary faulting locally reactivated preexisting crustal weaknesses. The studied faults also have low long-term slip rates, which are several orders of magnitude slower than faults in more active settings (e.g. 1-2 mm per year in southwestern United States: Machette 1998), and have long recurrence intervals of up to $>83000$ years.

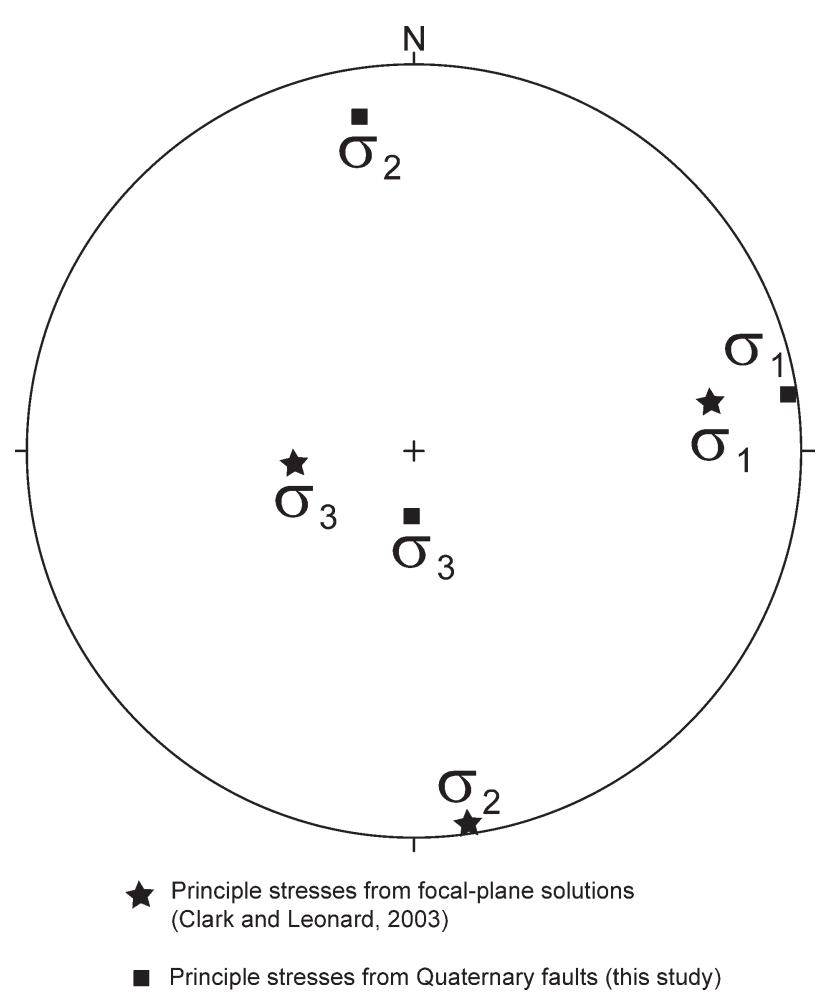

Figure 5 Comparison of principal compressive stresses derived from eight focal-plane solutions of Flinders Ranges earthquakes for the interval 1977-1991 (Clark \& Leonard 2003) and from field measurements of the Wilkatana, Burra, and Mundi Mundi Faults (this study). Stress magnitudes are defined such that compressive stresses are positive and $\sigma_{1}$ $>\sigma_{2}>\sigma_{3}$ so that $\sigma_{1}$ is the maximum principle compressive stress, and $\sigma_{3}$ is the minimum compressive stress. 
Our preferred estimates for the earthquake $\mathbf{M}$ represented by these fault scarps range from $\sim 6.6$ to 7.3, higher than the largest historic earthquake recorded in the Flinders Ranges (Greenhalgh et al. 1994) but similar to the largest historically recorded earthquakes in Australia [1968 Meckering earthquake, $M_{\mathrm{S}} 6.8$ (Gordon \& Lewis 1980); 1988 Tennant Creek earthquake, $\mathrm{M}_{\mathrm{S}}$ 6.3-6.7 (Crone et al. 1992)] and lower than the largest historical earthquake in a stable continental region (1819 Kutch, India, earthquake, M 7.5: Oldham 1926). These results confirm our suspicion that large magnitude events are largely under-represented in the Australian historical seismic record, and that events approaching the maximum $\mathbf{M}$ estimates for intracontinental regions may be present in the geological record (Greenhalgh et al. 1994).

Where the Wilkatana and Mundi Mundi Faults differ from typical intracontinental faults is that they define the topographic edges of rugged ranges and are thus linked strongly to the geomorphological record. Although the rates at which individual fault strands deform the surface appear to be slower than the rates at which surficial processes modify the landscape, as is the case for the Burra Fault, the Wilkatana and Mundi Mundi Faults are both composed of closely spaced fault networks whose cumulative movements appear to have outpaced geomorphic processes. The geomorphic imprint left by range-front faulting includes valley-invalley structures, formed from the rapid propagation of tectonic knickpoints through catchment systems.

The concentration of both contemporary seismicity and a rich neotectonic record in the Flinders Ranges (Sandiford 2003) suggests that this region has persisted as a zone of crustal weakness from its genesis during Neoproterozoic rifting to its present characterisation as an intracontinental seismic belt. The pre-existing structural and lithologic grain developed during this longlived tectonic history has undoubtedly exerted some mechanical control on the geometry and attitude of Quaternary faulting, as evidenced in the Burra and Mundi Mundi localities. The Flinders Ranges crust is also characterised by anomalously elevated heat flow related to high concentrations of heat-producing elements in Proterozoic basement rocks (Neumann et al. 2000). In addition to partitioning far-field stresses into a narrow deformation zone, these characteristics may have influenced the style of tectonism. Célèrier et al. (2005) suggest that the gross structure of the Flinders Ranges, characterised by a broad uplift bound by gently outward sloping basins, is a result of long-wavelength ( $\sim 150 \mathrm{~km})$, low-amplitude $(200-500 \mathrm{~m})$ crustal folding. In this model, the distribution of upper crustal faulting reflects spatial variations in lithospheric strength controlled by its thermal structure.

Despite the influence that these geological heterogeneities may have had on the distribution and geometry of Quaternary faulting and may continue to have on contemporary faulting (Clark \& Leonard 2003), palaeo-maximum compressive stress orientations $\left(\sigma_{1}\right)$ derived from the neotectonic record are generally consistent with those derived from active seismicity (Figure 5). Coblentz et al. (1995) and Sandiford (2003) attributed the approximate east-west trend in $\sigma_{1}$ to coupling interactions along the Pacific-Australia plate boundary and, more specifically, to the torques associated with the onset of transpressional tectonics and building of the Southern Alps in New Zealand at ca 10-6 Ma (Norris et al. 1995; Walcott 1998). Regional-scale tilting, basin inversion and localised uplift and erosion marked the terminal Miocene-Early Pliocene onset of this presently active regime (Sandiford 2003). The intraplate deformation and associated landscape evolution documented in the Flinders Ranges supports the notion that plate-boundary interactions can propagate stresses thousands of kilometres into plate interiors (Coblentz et al. 1995, 1998) and that slowly deforming intracontinental regions can provide insight into the temporal evolution of far-field plate boundaries.

The increasing recognition of Quaternary faults and related landforms in Australia, together with recent advances in Quaternary dating techniques, will inevitably lead to a better understanding of Australian palaeoseismicity and its geomorphic implications. However, preservation of Quaternary fault scarps in the rock record may be limited, highly variable and dependent on local geomorphic and geological factors. In areas of notable relief such as the Flinders and Barrier Ranges, inferred Quaternary range-bounding faults are rarely exposed due to burial by sediments derived from the adjacent range front. Furthermore, Quaternary movement on faults displacing ancient bedrock units is difficult to distinguish from ancient faulting, particularly in the absence of distinct geomorphic markers.

\section{CONCLUSIONS}

Our investigation of three well-exposed Quaternary faults in southern Australia concludes that: (i) a series of large M earthquakes associated with surface-rupturing reverse faults have occurred on the studied faults during the last $\sim 100000$ years, implying that future events should be expected for these regions; (ii) the neotectonic record of Quaternary faulting is consistent with aspects of the historical seismic record, justifying an extrapolation of historical seismicity over geological time-scales; (iii) past and present seismicity is reflected in the geomorphology of the Flinders and Barrier Ranges landscape and is controlled by local geological features, regional geological features and the mode of deformation; and (iv) the increasing recognition of neotectonic structures suggests that assessments of Australian seismic risk should incorporate the neotectonic record and that previous estimates may have underestimated seismic risk. Future surface-rupturing, large $\mathbf{M}$ earthquakes should be expected in the interior of continental Australia, particularly in regions of elevated contemporary seismicity and/or youthful geomorphic features.

\section{ACKNOWLEDGEMENTS}

Dan Clark, Steven Hill and Chris Wilson are thanked for critical reviews of draft manuscripts that greatly improved this paper. We thank Wolfgang Preiss for drawing our attention to the Burra locality and Geoscience 
Australia for contributing financial support. Andrew Smart is thanked for access to the Wilkatana property.

\section{REFERENCES}

ADAMIEC G. \& AitKen M. J. 1998. Dose-rate conversion factors: update. Ancient TL 16, 37-50.

AitKen M. J. 1998. An Introduction to Optical Dating: The Dating of Quaternary Sediments by the Use of Photon-stimulated Luminescence. Oxford University Press, Oxford.

Alley N. F. \& Benbow M. C. 1995. Tertiary. In: Drexel J. F. \& Preiss W. V. eds. The Geology of South Australia, Volume 2, Phanerozoic, pp. 219-281. Geological Survey of South Australia Bulletin 54.

BOURMAN R. P. \& LiNDSAY J. M. 1989. Timing, extent and character of late Cainozoic faulting along the eastern margin of the Mount Lofty Ranges, South Australia. Transactions of the Royal Society of South Australia 113, 63-67.

Bowler J. M., Johnston H., Olley J. M., Prescott J. R., Roberts R. G., SHAwCross W. \& SPOONER N. A. 2003. New ages for human occupation and climatic change at Lake Mungo, Australia. Nature 421, 837-840.

BowmAN J. R. \& DEWEy J. L. 1991. Relocation of teleseismically recorded earthquakes near Tennant Creek, Australiaimplications for midplate seismogenesis. Journal of Geophysical Research 96, 11973-11979.

Callen R. A., Sheard M. J., Benbow M. C. \& Belperio A. P. 1995. Alluvial fans and piedmont slope deposits. In: Drexel J. F. \& Preiss W. V. eds. The Geology of South Australia, Volume 2, Phanerozoic, pp. 241-243. Geological Survey of South Australia Bulletin 54

CAllen R. A. \& TedFord R. H. 1976. New late Cainozoic rock units and depositional environments, Lake Frome Area, South Australia. Transactions of the Royal Society of South Australia 100, $125-167$.

CÉlèrier J., SANDiford M., HANSEn D. L. \& Quigley M. 2005. Modes of active intraplate deformation, Flinders Ranges, Australia. Tectonics 24.

Clark D. J., Cupper M., SANDIFord M. \& Kiernan K. Style and timing of late Quaternary faulting on the Lake Edgar Fault, southwest Tasmania, Australia: implications for hazard assessment in intracratonic areas. Geological Society of America Special Paper (in press).

ClARK D. J. \& LEONARD M. 2003. Principal stress orientations from multiple focal plane solutions: new insight in to the Australian intraplate stress field. In: Hillis R. R. \& Müller R. D. eds. Evolution and Dynamics of the Australian Plate, pp. 85-99. Geological Society Australia Special Publication 22 and Geological Society of America Special Paper $\mathbf{3 7 2}$.

ClARK D. J. \& McCuE K. 2003. Australian palaeoseismology: towards a better basis for seismic hazard estimation. Annals of Geophy sics 46, $1087-1105$.

Coblentz D., SANDiford M., Richardson R., ZHOU S. \& Hillis R. R. 1995. The origins of the Australian stress field. Earth and Planetary Science Letters 133, 299-309.

CoBlEnTZ D., ZHOU S., HILlis R. R., RichARDSON R. \& SANDIFORD M. 1998. Topography, plate-boundary forces and the Indo-Australian intraplate stress field. Journal of Geophysical Research 103,919-931.

Crone A. J., De Martini P. M., Machette M. N., OKumura K. \& PRESCOTT J. R. 2003. Palaeoseismicity of two historically quiescent faults in Australia-implications for fault behaviour in stable continental regions. Seismological Society of America Bulletin 93, 1913-1934.

Crone A. J. \& LUZA K. V. 1990. Style and timing of Holocene surface faulting on the Meers fault, southwestern Oklahoma Geological Society of America Bulletin 102, 1-17.

Crone A. J., Machette M. N. \& Bowman J. R. 1992. Geologic investigations of the 1988 Tennant Creek, Australia, earthquakes-implications for palaeoseismicity in stable continental regions. US Geological Survey Bulletin 2032-A.

CRONE A. J., MACHeTte M. N. \& BowmAn J. R. 1997. Episodic nature of earthquake activity in stable continental regions revealed by palaeoseismicity studies of Australian and North American Quaternary faults. Australian Journal of Earth Sciences 44 $203-214$.
Dalgarno C. R., Johnson J. E., Forbes B. G. \& Thomson B. P. 1968 Port Augusta Map Sheet, Geological Atlas of South Australia, 1:250 000 Series. Geological Survey of South Australia, Adelaide.

Duller G. A. T. 1999. Analyst Version 2.12. Luminescence Laboratory, University of Wales, Aberystwyth.

EvERnDEN J. F. 1970. Studies of regional seismicity and associated problems. Seismological Society America Bulletin 60, 393-446.

Fowler C. M. R. 1990. The Solid Earth: an Introduction to Global Geophysics. Cambridge University Press, Cambridge.

GAlbraith R. F., Roberts R. G., LAslett G. M., YoshidA H. \& Olley J. M. 1999. Optical dating of single and multiple grains of quartz from Jinmium rock shelter, northern Australia: Part I, experimental design and statistical models. Archaeometry 41, $339-364$.

Gibson G. M., Owen A., Drummond B., Fomin T., Maidment D. W. \& WAKE-DYSTER K. 1997. Crustal structure in the Broken Hill region as evidenced by deep seismic reflection profiling and structural mapping. In: Denham D. compiler, Broken Hill Exploration Initiative: Abstracts from 1997 Annual Meeting, pp. 43-44. Australian Geological Survey Organisation Record $1997 / 49$.

GIBSON H. J. \& STÜWE K. 2000. Multiphase cooling and exhumation of the southern Adelaide Fold Belt: constraints from apatite fission track data. Basin Research 12, 31-45.

GoRDON F. R. \& LEWIS J. D. 1980. The Meckering and Calingiri earthquakes October 1968 and March 1970. Geological Survey of Western Australia Bulletin 126.

Greenhalgh S. A., Love D., MalPas K. \& McDougall R. 1994. South Australian earthquakes, 1980-92. Australian Journal of Earth Sciences 41, $483-495$.

Greenhalgh S. A., Singh R. \& PARHAM R. T. 1986. Earthquakes in South Australia. Transactions of the Royal Society of South Australia 110, 145-154.

HANKS T. C. \& KANAMORI H. 1979. A moment-magnitude scale. Journal of Geophysical Research 84, 2348-2350.

Haviv I., Enzel Y., Whipple K., Zilberman E., Stone J., Matmon A. \& FIFIELD L. 2003. Knickpoint retreat and drawdown reach evolution along the arid escarpments of the Dead Sea Basin Geological Society of America Abstracts with Programs 35, 333.

HiLl S. M. \& KoHN B. P. 1999. Morphotectonic evolution of the Mundi Mundi range front, Broken Hill region, western NSW. In: Taylor G. \& Pain C. eds. New Approaches to an Old Continent, 3rd Australian Regolith Conference Proceedings, Regolith '98, pp. 319 -334. Cooperative Research Centre for Landscape Evolution and Mineral Exploration, Perth.

Hillis R. R. \& REYNOLDS S. D. 2000. The Australian stress map. Journal of the Geological Society of London 157, 915-921.

Johnston A. C., Coppersmith K. J., KANTER L. R. \& Cornell C. A. 1994. The earthquakes of stable continental regions. Electric Power Research Institute Publication TR-102261-V1.

Klepeis K., Claypool A. \& TOKE N. 2002. Dynamic topography in transpressional regimes: an example from the New Zealand plate boundary zone. Geological Society of America Programs with Abstracts, Northeastern Section Session 34, 1.

LANGSTON C. A. 1987. Depth of faulting during the 1968 Meckering, Australia, earthquake sequence determined from waveform analysis of local seismograms. Journal of Geophysical Research 92, $11561-11574$

MACHETTE M. N. 1998. Contrasts between short- and long-term record of seismicity in the Rio Grande Rift-important implications for seismic assessments in areas of slow extension. Utah Geological Society Miscellaneous Publications 98-2, 84-95.

Machette M. N., Crone A. J. \& Bowman J. R. 1993. Geologic investigations of the 1986 Marryat Creek, Australia, earthquake-implications for palaeoseismicity in stable continental regions. US Geological Survey Bulletin 2032-B.

McCuE K. 1990. Australia's large earthquakes and Recent fault scarps. Journal of Structural Geology 12, 761-766.

MCLAREN S., DunlaP W. J., SANDIFORD M. \& MCDOUGALL I. 2002. Thermochronology of high heat-producing crust at Mount Painter, South Australia: implications for tectonic reactivation of continental interiors. Tectonics 21(4), 1020, doi:10.1029/ $2000 \mathrm{TC} 001275$.

MANDL G. 1988. Mechanics of Tectonic Faulting (Developments in Structural Geology 1). Elsevier, Amsterdam.

MAWson D. 1912. Geological investigations in the Broken Hill area. Memoirs of the Royal Society of South Australia 2, 211-319. 
MEJDAHL V. 1979. Thermoluminescence dating: beta-dose attenuation in quartz grains. Archaeometry 21, 61-72.

MurRAY A. S. \& RoBERTS R. G. 1998. Measurement of the equivalent dose in quartz using a regenerative-dose single-aliquot protocol. Radiation Measurements 29, 503-515.

MuRRAY A. S. \& WinTLE A. G. 2000. Luminescence dating of quartz using an improved single-aliquot regenerative-dose protocol. Radiation Measurements 32, 57-73.

NEUMANN N., SANDIFORD M. \& FODEN J. 2000. Regional geochemistry and continental heat flow: Implications for the origin of the South Australian heat flow anomaly. Earth and Planetary Science Letters 183, 107-120.

NORRIS R. J., KoONS P. O. \& COOPER A. L. 1995. The obliquely converging plate boundary in the South Island of New Zealand: implications for ancient collision zones. Journal of Structural Geology 12, 715-725.

NotT J., Young R. \& McDougall I. 1996. Wearing down, wearing back, and gorge extension in the longterm denudation of a highland mass: quantitative evidence from the Shoalhaven Catchment, Southeast Australia. Journal of Geology 104, $224-232$.

OLDHAM R. D. 1926. The Cutch (Kachh) earthquake of 16th June 1897. Geological Society of India Memoir 46.

Olley J. M., Pietsch T. \& RoBerTs R. G. 2004. Optical dating of Holocene sediments from a variety of geomorphic settings using single grains of quartz. Geomorphology 60, 337-358.

OlLIER C. D. 1978. Tectonics and geomorphology of the Eastern Highlands. In: Davies J. L. \& Williams M. A. J. eds. Landform Evolution in Australia, pp. 5-47. ANU Press, Canberra.

Phillips W. M., Commins D. \& GuPTA S. 2003. Rates of knickpoint migration and bedrock erosion from cosmogenic Be-10 in a landscape of active normal faulting. Geological Society of America Abstracts with Programs 35, 63.

PREISS W. V. \& FAULKNER P. 1984. Geology, geophysics and stratigraphic drilling at Depot Creek, Southern Flinders Ranges. Geological Survey of South Australia Quarterly Geological Notes 89, $10-19$.

PRESCOTT J. R. \& HUtTon J. T. 1994. Cosmic ray contributions to dose rates for luminescence and ESR dating: large depths and long-term time variations. Radiation Measurements 23, 497-500.

Quigley M. C., SANDiford M., CuPPer M. \& Alimanovic A. 2004. Quantifying South Australian landscape evolution, Geological Society of America Abstracts with Programs 36, 5.

SANDIFORD M. 2003. Neotectonics of southeastern Australia: linking the Quaternary faulting record with seismicity and in situ stress. In: Hillis R. R. \& Müller R. D. eds. Evolution and Dynamics of the Australian Plate, pp. 101-113. Geological Society of Australia, Special Publication 22 and Geological Society of America Special Paper 372.

SANDIFORD M., WALLACE M. \& COBLENTZ D. 2004. Origin of the in situ stress field in southeastern Australia. Basin Research 16, $325-338$.

SPRIGG R. C. 1945. Some aspects of the geomorphology of a portion of the Mount Lofty Ranges. Transactions of the Royal Society of South Australia 69, 277-304.
Stevens B. P. J. 1980. A guide to the stratigraphy and mineralization of the Broken Hill Block, New South Wales. Geological Survey of New South Wales Records 20.

Stevens B. P. J. 1986. Post-depositional history of the Willyama Supergroup in the Broken Hill Block, NSW. Australian Journal of Earth Sciences 33, 73-98.

Stevens B. P. J. \& CoRbETT G. J. 1993. The Redan Geophysical Zone, part of the Willyama Supergroup? Broken Hill, Australia. Australian Journal of Earth Sciences 40, 319-338.

SylVESTER A. G. \& SMITH R. R. 1976. Tectonic transpression and basement-controlled deformation in San Andreas Fault Zone, Salton Trough, California. In: Sylvester A. G. ed. Wrench Fault Tectonics, pp. 173-194. American Association of Petroleum Geologists Reprint Series 28.

Thorne A., GrÜn R., Mortimer G., Simpson J. J., McCulloch M., TAYLOR L. \& CURNOE D. 1999. Australia's oldest human remains: age of the Lake Mungo skeleton. Journal of Human Evolution 36, $591-612$

TOKAREV V., SANDIFORD M. \& Gostin V. 1999. Landscape evolution in the Mount Lofty Ranges: implications for regolith development. In: Taylor G. \& Pain C. eds. New Approaches to an Old Continent, 3rd Australian Regolith Conference Proceedings, Regolith '98, pp. 127-134. Cooperative Research Centre for Landscape Evolution and Mineral Exploration, Perth.

TwiDAle C. R. 1983. Australian laterites and silcretes-ages and significance. Revue de Géologie Dynamique et de Géographie Physique 24, 35-45.

TwidALE C. R. \& BouRnE J. A. 1975. Geomorphological evolution of part of the eastern Mount Lofty Ranges, South Australia. Transactions of the Royal Society of South Australia 99, 197-210.

VAN DER BEEK P., PUlFord A. \& BRAUN J. 2001. Cenozoic landscape development in the Blue Mountains (SE Australia): lithological and tectonic controls on rifted margin morphology. Journal of Geology 109, 35-56.

WALCOTT R. I. 1998. Modes of oblique compression: late Cainozoic tectonics of the South Island of New Zealand. Reviews of Geophysics 36, 1-26.

WASSON R. J. 1978. Sedimentation history of the Mundi Mundi alluvial fans, western New South Wales. Sedimentary Geology 22, $21-51$.

WeLlman P. \& GREenHALGH S. 1988. Flinders/Mount Lofty Ranges, South Australia: their uplift, erosion and relationship to crustal structure. Transactions of the Royal Society of South Australia 111, $11-19$.

WeLLS D. L. \& COPPERSMITH K. J. 1994. New empirical relationships among magnitude, rupture length, rupture width, rupture area, and surface displacement. Seismological Society America Bulletin 84, 974-1002.

WILLIAMS G. E. 1973. Late Quaternary piedmont sedimentation, soil formation and palaeoclimates in arid South Australia. Zeitschrift für Geomorphologie 17, 102-125.

Received 4 April 2005; accepted 3 November 2005 
